\title{
AZ AKADÉMIAI KIVÁLÓSÁG IGAZI LETÉTEMÉNYESEI \\ THE TRUE TRUSTEES OF THE ACADEMIC EXCELLENCE
}

\author{
Patkós András \\ PhD, emeritus egyetemi tanár, Eötvös Loránd Tudományegyetem \\ patkos@galaxy.elte.hu
}

\begin{abstract}
ÖSSZEFOGLALÁS
Felsorolásszerűen áttekintem az akadémiai kiválóság fogalmának modern összetevőit. Megfogalmazom állításom, miszerint ennek valódi letéteményese azoknak a tudományos személyiségeknek spontán kifejlődő hálózata, akiknek egyetemi víziója egyszerre mutatja fel a tudományos kiválóság, a tanítási és intézményi innováció és az elkötelezett társadalomszolgálat ismérveit. Az egyetemi szervezetnek e vízió hatékony valóra váltását kell szolgálnia.
\end{abstract}

\begin{abstract}
Modern components of academic excellence are shortly enumerated. I claim that spontanously developing networks of scientific personalities with strategic university vision validated by scientific excellence, original teaching and organisatory innovations, and social commitment represent the true trustees of the excellence of any university. University boards and committees should serve the efficient realisation of that vision.
\end{abstract}

Kulcsszavak: egyetemi testületek, tudományos szuverenitás, oktatásipar, tudományipar

Keywords: university boards, scientific sovereignty, education and science industry

Az ,akadémiai kiválóság” fogalmát a nemzetközi tudományos életben és a szakpolitikában az egyetemeken folytatott magas színvonalú oktatás és kutatás öszszefoglaló jellemzésére használják. A kiválóság az egyetemi polgárok (tanárok és diákok) együttmüködő tevékenységében jelenik meg. Az egyetemi szervezet, az oktatási és kutatási infrastruktúra elsődleges feladata az akadémiai kiválóság erősítése.

E megállapításokat könnyü összekapcsolni Eötvös Lorándnak az iskolarendszer 1870-es évtizedben zajló átalakítása során tett kijelentésével, amelyben a tanítási rendszer és a tanárok közül egyértelmüen az utóbbiak minőségét tartotta fontosabbnak. 
Ebben az írásban vázlatosan, néhány kommentár kíséretében bemutatom az akadémiai kiválóságnak a mai korban meghatározó, a klasszikus egyetemfelfogáshoz képest kibővült ismérveit. Az ezt követő függelékben egy közelmúltbeli példával illusztrálom, hogy az egyetemi élet szellemi központjai azok körül alakulnak ki, akiknek tevékenységében az akadémiai kiválóság többféle ismérve egymást erősítve, egyszerre nyilvánul meg.

1. Az akadémiai kiválóság jellemzőinek sokféleségében minden oktató-kutató elengedhetetlen vonása, hogy tudományos érdeklődése messze túlnyúlik saját kutatási témáin. Ez alapkövetelmény!

A tudományos kíváncsiságnak az egész életpályát végigkísérő önképzésben megnyilvánuló megőrzése a tanársegédtől a professzorig megkülönböztető jegye az egyetemi oktatóknak-kutatóknak - összehasonlítva egy kutatóintézet, egy innovációs vagy oktatási vállalkozás valamely célfeladatra fókuszáltan specializálódó munkatársaival. A kutatóintézetekbe távozott egykori kollégáimat a kizárólagosan a kutatásra koncentrált erőfeszítés lehetősége vonzotta. A kutatóintézetekből érkezők, illetve részfoglalkozásúként az egyetemi oktatásban tartósan elkötelezettek mindegyikét a diszciplínákat átfogó gondolkodásra való törekvés jellemezte.

2. A kutatási intenzitás és eredményesség mérőszámokkal való jellemzését nemcsak a laikus társadalom használja gyors véleményalkotásra, de a szükebb szakma is növekvő súlyt ad a tudományos pályázatok, előléptetési/díjazási javaslatok mérlegelésében a hivatkozási és rangsorstatisztikáknak. E mérőszámok valóban jól jelzik a kutatások nemzetközi beágyazottságát, a kutatómunka és közzététele rendszerességét. Ám az akadémiai kiválóság letéteményeseinek azonosításához ez nem elégséges!

A kutatói kiválóság elsődleges mutatója a személyiség tudományos szuverenitásából fakadó hatása a kutatói közösségre. Kiemelkedő professzoroktól elvárható, hogy elsőként vessenek fel nemzetközi figyelmet keltő kutatási témákat, és képesek legyenek a megvalósításukra vállalkozó projektek szakmai menedzselésére. Alacsonyabb szinten járul hozzá az akadémiai kiválósághoz egy nagy hivatkozottságú globális tudományos projekt rendszeres szorgalmas bedolgozója, mint e kutatás „tudományos szóvivője”.

3. A tanításra, témavezetésre való rátermettség a végleges egyetemi állás elnyerésének kötelező előfeltétele. Eötvös Loránd örök érvényü igazsága, hogy egyetemen motiválóan tanítani az tud, akinek jelentős (pozitív) kutatási tapasztalata van.

Az új eredményeket folyamatosan integráló egyetemi oktatás megújításához kívánatos, hogy időszakosan világhírủ kutatók is vállaljanak alapképzési feladatot. Világkarriert befutott példa: Richard Feynman három féléves kurzusa a 
California Institute of Technology bármely szakos „freshman”-jeinek, amelyben vállalta a differenciál- és integrálkalkulus, a vektorszámítás vagy a differenciálegyenletek numerikus megoldásai alapvető algoritmusainak részletekbe menő, egyben a haladóbb fejezetek felé elöremutató megjegyzésekkel egyénített tárgyalását. Mindehhez hozzáfüzte a tudomány és a társadalom, a tudomány és a müvészetek vagy a filozófia viszonyára vonatkozó sarkos észrevételeit. E nagy formátumú személyiség előadásának a szavakon túlmutató üzenetére negyedszázad múltán azok a hallgatói is emlékeztek, akiknek pályája messze kanyarodott a mérnöki-fizikusi iránytól. Ismerünk hasonló hazai példákat, tudjuk, hogy ezek alapozzák meg egy-egy egyetem szélesebb társadalmi ismertségét.

Ma már általánosan elfogadott, hogy a tudománytörténet döntő felismeréseinek, a tudományos eredmények történelmet változtató felhasználási példáinak átgondolt bemutatása önálló tudományos alapokkal bíró módszertani fejlesztést követel. Egyetemeink belső közvéleménye tudománymetriai adatoknak fittyet hányva tartja számon az előadózseniket, a laborvezető mágusokat, az enciklopédikus tudással tanácsot adni képes kollégákat. Ök állhatnának a középiskolásokat az egyetemi diszciplinákra motiváló tudásátadást megújító, a felsőoktatás első évfolyamain jelentkező pedagógiai kihívásokra választ adni képes kutatások-fejlesztések élvonalában. Ám a tanitói kiválóságnak hazánkban nincs a kutatói teljesitményhez hasonló kifutása. Eközben világszerte növekvő figyelmet kap a szaktudományok tanításának módszertana, melynek révén az egyetemek diszciplináris intézeteiben növekvő számban jelennek meg a szakterület tantárgy-pedagógiáját kutató professzorok és tanítási innovációik gyakorlati hasznosítására köréjük szerveződő csoportok. Időszerü lenne itthon is megnyitni azok számára ezt a szakmai karrierívet, akik túllépve az oktatási performansz ösztönös hatásosságán, kutatói programban képesek feltárni (és örökíthetővé tenni) annak tudományos alapjait. A lényeg, hogy a tantárgy-pedagógia (content pedagogy) területén nemzetközileg is elismerést elérő legjobbak elött teljes egyetemi perspektíva álljon, hogy ne ítéltessenek az eleve másodrangú „,szolgáltató oktató" szerepére.

4. Menedzseri kiválóság. A nagy léptékű tudományos és oktatási projektek (az oktatás- és tudományipar) szervezői, kutatásvezetői kiválóságának elismerése a tudományos közösségben is vita tárgya. Önálló ismérveinek megfogalmazása segít, hogy ne keverjük össze a tudományos kutatói kiválósággal, egyben utat nyit sajátos értékei szerinti elismeréséhez.

Az ún. „,nagy tudomány” műveléséhez, a diszciplinárisan összetett nagy egyetemek müködéséhez elengedhetetlen a menedzseri közremüködés. Elismerést érdemel, ha valaki kiemelkedő oktatói-kutatói pályája részeként vállalja egy nagy költségü/kockázatú projekt irányításának menedzseri felelősségét (lásd 2. pont). Terjed, hogy ilyen jellegü projektek müködtetésére az ipar vagy az igazgatás álta- 
lános rendszeréből hívnak meg vezetőket. Ez elismerendő szolgálat, de önmagában nem alap az akadémiai kiválóságra.

5. Társadalmi felelősség. A magas szintű tudásra épülő eszközök és eljárások szélesedő használatával párhuzamosan növekvő felelősséggel tartoznak az akadémiai kiválóság hordozói a laikus társadalom bizalmának megszerzéséért és fenntartásáért.

A klasszikus ismeretterjesztő tevékenységen túllépve, a döntéshozatalban való részvétel demokratikus jogának nem formális gyakorlására fel kell készíteni a közvéleményt. A szemléletalakítás fórumainak létrehozását immár nemcsak az egyetemek, hanem a kutató-fejlesztő intézetek is kiválósági jegyeik között tartják számon. (Hazánkban is gyorsabban haladna ez az ügy, ha néhány éve a természettudományi kommunikációs mesterszakot nem szüntette volna meg a felsőoktatás „fura ura”.)

6. Gazdasági hasznosság. A piacgazdaság fokozódóan igényli az egyetemek intenzív részvételét az akadémiai tudást felhasználó, gazdasági hasznot hozó termékek létrehozásában.

A gazdasági partnerek stratégiai elkötelezettsége hozzájárul az egyetemek stabilitásához, az együttmúködés fontos karrierutat kínál a frissen végzetteknek és az egyetemi pályáról továbblépő munkatársaknak is. Az együttmüködés szakmai feladatainak teljesítése pozitív hozzájárulás az akadémiai kiválósághoz. Ám a rutinszerü, tömeges célzott munkaerőképzés esetleges dominanciája ezt megkérdőjelezi.

\section{ÖSSZEGZÉS}

Akadémiai kiválósági jegyekkel - a karrierszakasz, képesség és életkor függvényében változó mértékben - az egyetemi oktatók-kutatók mindegyikének rendelkeznie kell. Az akadémiai kiválóság letéteményeseitől („zászlóvivőitől”) elvárható, hogy pályájuk csúcsán (egy-két évtizedig) a felsorolt kiválósági jegyek többségét egyidejűleg mutassák fel, és intézményi perspektívát adó víziót építsenek rá. Munkásságuk jellege időben változhat, a hangsúly hol a kutatásra, hol a tanításra, hol az intézményszervezésre kerül, a kutatóprofesszor megkülönböztető megnevezés túl merev korlátot jelent számukra.

Egy tudományegyetemi karon minden időben elengedhetetlen négy-öt meghatározó, saját kutatási területén messze túllátó, az intézmény egészének irányt mutató kiválóság aktiv müködése (példaként lásd Appendix). Hiányukban az egyetemi müködés ideális tökéletességü rendszere is terméketlen, a kialakitására forditott energia elfecsérelt! 
Az egyetemi közélet önszervező folyamatai akkor egészségesek, ha centrumában mindenkor az akadémiai kiválóság igazi letéteményesei állnak. Számuk jóval kisebb a saját területén kiváló teljesítményủ professzorokénál, mégis, a csoport tagjai között spontán alakuló látens együttmüködési hálózat ad arculatot és fejlődési irányt az intézménynek. Az intézményi autonómia akkor működik, ha a szervezeti vezetés (legyen az kuratórium, szenátus, kari tanács, vezetői értekezlet) e fejlődési irányokat képes intézményi stratégiává emelni, és megvalósításukra növekvő mértékben szellemi és materiális eszközöket bevonni. Ahol ez a csoport nem tud kialakulni, teret kap a testületeken belüli és közötti alkuk sorozatából álló, kizárólag a rövid távú túlélésre koncentráló intézményi működés.

Kiegészítő szómagyarázat: Hozzászólásom eredeti címének angol fordítása The Trustees of the Academic Excellence lett volna. Ezzel zavart okozó megnevezésbeli egybeesés keletkezett volna az egyetemi átalakulásról szóló vitát összefoglaló szerkesztőbizottsági cikkben kiemelten hivatkozott, az észak-amerikai egyetemi modellben meghatározó Board of Trustees intézményével. Mondandóm középpontjában éppen az a tézisem áll, hogy a kuratóriumok, szenátusok és kari tanácsok müködésének lényege az akadémiai kiválóság fentebb ismertetett korszerü jegyeit hordozó, kis létszámú professzori csoport víziójának intézményi stratégiává alakítása. Ezt a lényegi eltérést az észak-amerikai modelltől kívánja sugallni az új cím magyarul és angolul is: The True Trustees of the Academic Excellence.

\author{
APPENDIX \\ Marx György (1927-2002) csodálatos évtizede (1970-1980)
}

Az akadémiai kiválóság jegyeinek majdnem teljességét a pályája csúcsát jelentő 1970-es évtizedben felvonultató professzor tevékenységét tényszerüen idézem fel. Itt (egyébként tartós) szellemi hatásának értékelésével nem próbálkozom.

A neutrínó-asztrofizika egyik ,alapító atyja”, aki elsőként adott 1972-ben, majd 1976-ban a neutrínók tömegére kozmológiai felső korlátot, majd tett javaslatot a neutrínók hozzájárulására a világegyetem sötét anyagához. Elsőként végzett számítási becslést (1971) a földkéreg radioaktív izotópjainak bomlásából származó neutrínófluxus nagyságára.

1972-ben Magyarországra összehívta az I. Nemzetközi Neutrínó Konferenciát, amely két, akkor már Nobel-díjas és három, a díjat a későbbiekben elnyert kutató részvételével kijelölte a neutrínókutatást máig meghatározó irányokat. Az idén 30. konferenciáját rendező sorozat tudományos bizottságának egészen haláláig (2002) elnöke, és további magyarországi neutrínókonferenciák szervezője volt $(1975,1982)$. 
Személyes elkötelezettséggel modernizálta az Eötvös Loránd Tudományegyetem (ELTE) biológus szak fizika-elóadásait (Életrevaló atomok, 1978). Az évtized közepén megalapította a fizikusképzés biofizikus szakirányát. Bizonyítványt adó sugárvédelmi tanfolyam indítását kezdeményezte az ELTE Atomfizikai Tanszékén.

Az MTA-nak a közoktatás modernizálására javaslatot készítő, Szentágothai János vezette bizottsága tagjaként új szemléletủ fizikatanítási programot alkotott (1976), amelynek kísérleti megvalósításában tankönyvíróként, valamint tanári továbbképzések oktatójaként vett részt. 1976-tól csatlakozott a fizikatanítás kutatásának meghatározó nemzetközi szervezetéhez (Groupe International de Recherche sur l'Enseignement de Physique, GIREP), amelynek hamarosan Board-tagja, majd elnöke lett.

Az Eötvös Loránd Fizikai Társulatnak 1972-től fötitkára, majd (elöször) 1980ig elnöke. A Fizikai Szemle főszerkesztője. Tudománynépszerüsítő cikkek és előadások sokaságát írta, illetve tartotta. A tudományos kutatás és a mủvészeti alkotás egységét keresve baráti kapcsolatot alakított ki, és nyilvános párbeszédet folytatott filmrendezőkkel, költőkkel, képzőmüvészekkel (például: Vilt Tibor életmü-kiállításának megnyitása, 1974; rádiómüsor Borsos Miklós, Déry Tibor és Keresztury Dezső társaságában, 1977). 